\title{
Effect of ovariectomy at two periods of the year on LH and FSH basal concentrations and pituitary response to LHRH in the brown hare (Lepus europaeus)
}

\author{
M. Caillol, M. Mondain-Monval*, M. Meunier and A. S. McNeilly† \\ Institut National de la Recherche Agronomique, Unité de Neurobiologie de la Reproduction, 78350 \\ Jouy-en-Josas, France; ${ }^{*}$ Fondation de Recherche en Hormonologie, 67-77 Boulevard Pasteur, \\ 94260 Fresnes, France; and $\dagger M R C$ Unit of Reproductive Biology, Centre for Reproductive Biology, \\ 37 Chalmers Street, Edinburgh EH3 9EW, UK
}

\begin{abstract}
Summary. In the brown hare, fertile mating takes place from the beginning of December to September. Seasonal variations of basal concentrations of LH and FSH, and pituitary response to a monthly i.v. injection of LHRH were studied in intact control females and in females ovariectomized during the seasonal anoestrus (OVX1) or during the breeding season (OVX2). In intact females, both basal and LHRHstimulated $\mathrm{LH}$ levels showed an annual variation, with minimal values during anoestrus. During the breeding season, the LH response to LHRH exhibited a biphasic pattern. In contrast, there was no clear seasonal variation in basal and LHRH-stimulated FSH concentrations. After ovariectomy during anoestrus, basal LH remained low for 2 months and began to increase in December. After ovariectomy during the breeding season, LH basal concentrations increased within a few days after the operation. Thereafter, LH values remained high in both groups of females until September, and decreased significantly as in intact females. The pattern of LH release after LHRH remained monophasic in the two groups of ovariectomized females. In OVX1 females, the $\mathrm{LH}$ response increased as early as October, was maximum from December to April and decreased progressively until October. In OVX2 females, the LH response decreased regularly after ovariectomy to a minimum in October. In the 2 groups of ovariectomized females, basal FSH concentrations and pituitary response to LHRH rose rapidly after ovariectomy and did not vary significantly thereafter. These results showed a direct central effect of season on the regulation of basal concentrations of $\mathrm{LH}$, modulated by a negative feed-back of ovarian secretions during the breeding season. In intact hares, the enhanced $\mathrm{LH}$ response after LHRH during the breeding season was related to an acute positive effect of ovarian secretions. The regulation of FSH was less dependent on season and remained under a negative control of the ovary throughout the year.
\end{abstract}

Keywords: brown hare; LH; FSH; LHRH; ovariectomy; season

\section{Introduction}

The brown hare, Lepus europaeus, is a seasonal polyoestrous induced ovulator: under natural conditions of daylength and temperature, the first fertile matings occur at the beginning of December, and the first parturitions take place at mid-January. The last matings occur at the beginning of September. Photoperiod is one of the factors regulating the length and timing of the breeding season (Martinet \& Moret, 1971; Meunier \& Martinet, 1986). In this species, the annual reproductive cycle is related to changes in $\mathrm{LH}$ basal concentrations and in the pituitary response to LHRH: both values increase from January to a maximum in July, and decrease in August to a 
nadir from September to December. From January to August, the pattern of LH release induced by an LHRH injection is modified and a 2nd peak of LH appears $2 \mathrm{~h}$ after injection (Caillol et al., 1986). Similar seasonal fluctuations of LH concentrations have been described by Davis \& Meyer (1973) for the snowshoe hare (Lepus americanus). To our knowledge, no data are available concerning seasonal variations of circulating FSH concentrations in the brown hare. The only information relates to the pituitary FSH content in the snowshoe hare in which minimal values in NovemberDecember are followed by an increase from March to a maximum in June (Davis \& Meyer, 1973).

In the first part of this paper, we have studied the seasonal variations of FSH (basal values and response to an exogenous LHRH stimulus). In the second part, we have determined the relative roles of ovarian secretions and of environmental cues on the regulation of both basal and LHRH-stimulated concentrations of LH and FSH.

\section{Materials and Methods}

Animals. Hares were born in captivity and kept isolated outdoors at weaning ( 1 month). The control and experimental females were 6 months old at the beginning of the experiment. Two groups of 6 females receiving alternately every 2 months an i.v. injection of $5 \mu \mathrm{g} \mathrm{LHRH}(1.7 \mu \mathrm{g} / \mathrm{kg}$ body weight; Stimu-LH: Roussel, Paris, France) were used as control. The basal and stimulated LH and FSH concentrations did not differ in these 2 groups of females and so the same symbol has been used in the figures. Two groups of 5 experimental females were ovariectomized under pentothal anaesthesia either during the seasonal anoestrus (19 September, OVX1) or during the breeding season (27 March, OVX2). They received an i.v. injection of $5 \mu \mathrm{g}$ LHRH before ovariectomy and once a month after ovariectomy.

Blood was obtained from the ear veins of unanaesthetized animals before LHRH injection and 15, 30, 60,90, 120 , $300 \mathrm{~min}$ and $24 \mathrm{~h}$ after injection. To study basal concentrations of LH and FSH, blood was sampled every 2 weeks around ovariectomy in experimental females. Serum samples were prepared after centrifugation at $4^{\circ} \mathrm{C}(5000 \mathrm{~g})$ and stored frozen until assayed.

Measurement of $\mathbf{L H}$. LH was measured as previously described (Mondain-Monval et al., 1985). The rabbit anti-ovine LH antiserum was kindly supplied by Dr G. D. Niswender (GDN 15); the highly purified sheep LH (LER 1056-C2) used as a tracer and the dog LH (LER 1685-1) used as a standard were provided by Dr L. E. Reichert. The sensitivity of the LH assay was $0.4 \mathrm{ng} / \mathrm{ml}$, and intra- and inter-assay coefficients of variation were 4 and $6 \%$, respectively.

Measurement of $\boldsymbol{F S H}$. Hare FSH was measured using a heterologous double-antibody radioimmunoassay as described previously for the fox (Mondain-Monval et al., 1988). The rabbit anti-human FSH antiserum (M 94) (McNeilly et al., 1976) was used with highly purified sheep FSH (LER-1976 A2) as tracer, and with a highly purified dog FSH preparation (LER-1685-3A) as standard, supplied by Dr L. E. Reichert.

The antiserum was characterized by McNeilly et al. (1976) and cross-reacts with FSH from several mammalian species. Parallelism in the displacement curves caused by dog FSH, sheep FSH and dilutions of hare pituitary extract or serum samples from ovariectomized hares was tested. The accuracy of the assay was determined by the measurement of known amounts of dog FSH or diluted hare pituitary extracts added to serum containing low levels of FSH. The detection limit was defined as the minimum concentration of dog FSH capable of causing a significant displacement $(P<0.05)$ of radiolabelled FSH from the antiserum. The precision was assessed by the repeated measurement of 2 pools of serum.

Because of a lack of a purified hare FSH, a highly purified dog FSH preparation was used as standard. The FSH values are expressed as $\mathrm{ng}$ LER-1685-3A equivalents $/ \mathrm{ml}$. Samples and reference preparations were measured in duplicate.

Statistical analysis. All concentrations of LH and FSH are expressed as mean \pm s.e.m. Data for measurements taken over time were compared by Student's $t$ test for paired dependent values for 2 successive samples. Data for nonrepetitive variables were analysed by analysis of variance. Differences between groups were assessed for significance by the LSD test.

\section{Results}

\section{Validation of the FSH assay}

Specificity. The method proved to be specific for hare FSH. The binding of ${ }^{125} \mathrm{I}$-labelled FSH to antiserum M 94 was displaced in a parallel manner by hare crude pituitary homogenates and purified dog FSH (Fig. 1). Serial dilutions of serum from ovariectomized doe hares were parallel to 
the inhibition curves obtained with hare pituitary extract and dog FSH (Fig. 1). Furthermore, high concentrations of $\mathrm{LH}$ in serum from pregnant hares injected with LHRH did not affect FSH values which remained undetectable. In contrast, all the hares showed an increase in FSH concentrations after ovariectomy (see below, Fig. 3).

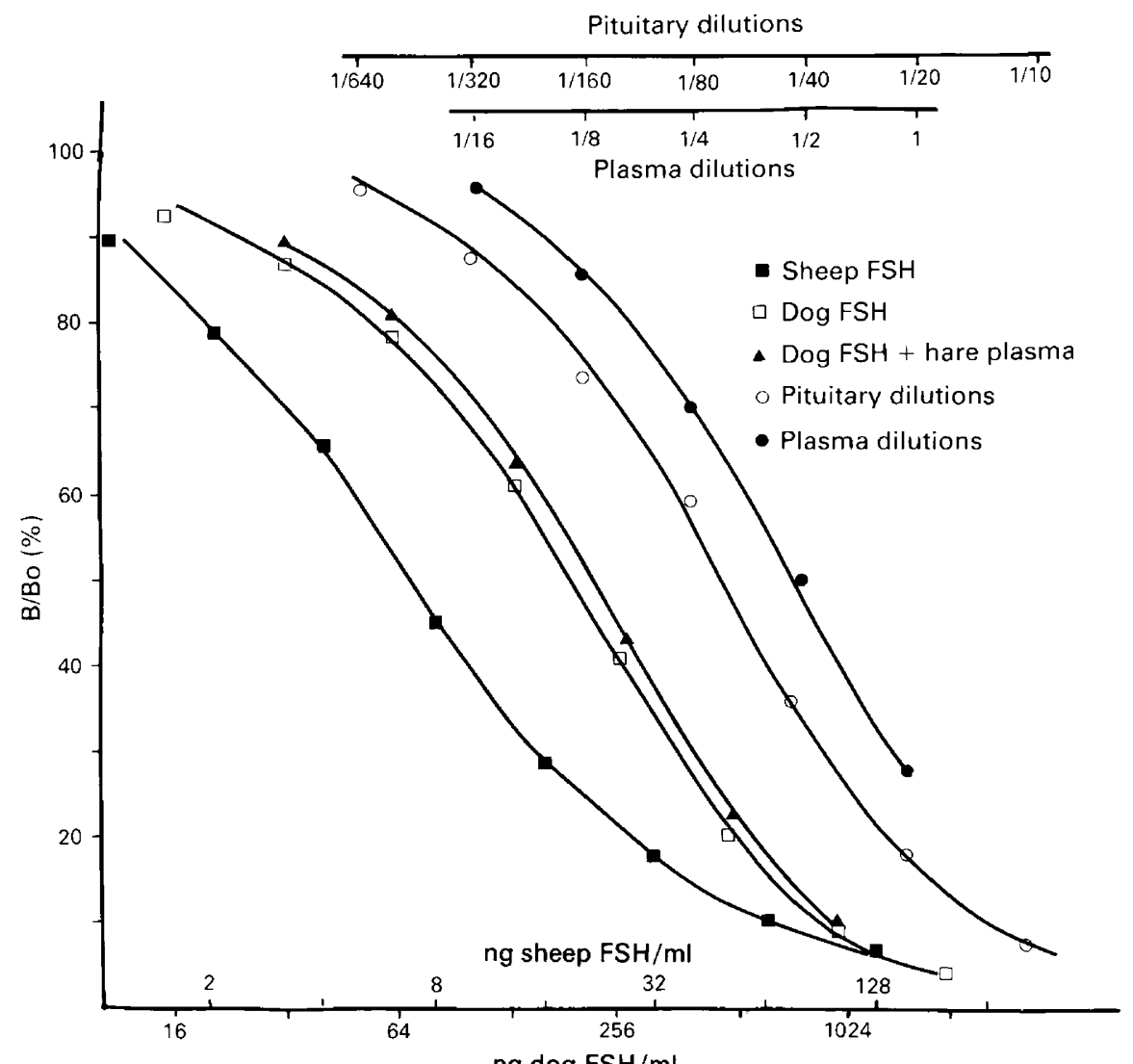

Fig. 1. Inhibition curves for dog FSH (LER 1685-3A) prepared in assay buffer with ( $\boldsymbol{\Delta}-\boldsymbol{\Delta}$ ) or without ( $\square-\square$ ) hare serum and dose-response curves for dilutions of pituitary extract $(\mathrm{O}-\mathrm{O})$ and for dilutions of serum from ovariectomized hares $(\bullet-0)$.

Accuracy. The recoveries of known amounts of dog FSH (16-2048 ng) added to serum from hares during anoestrus and previously measured at $<20 \mathrm{ng} / \mathrm{ml}$ were $96.8 \pm 5.0 \%$.

Sensitivity and precision. Under routine conditions the assay was sensitive to $20-30 \mathrm{ng} / \mathrm{ml}$ serum. The proportion of total radioactivity bound by the antiserum in the absence of hormone ranged from 15 to $35 \%$. The intra- and inter-assay coefficients of variation were 8.0 and $10.6 \%$, respectively.

\section{Annual variations of basal concentrations of LH and FSH in intact and ovariectomized females}

$\boldsymbol{L H}$. In intact females, $\mathrm{LH}$ values remained undetectable during seasonal anoestrus, and rose slightly from March to August (Fig. 2).

In females ovariectomized during the seasonal anoestrus (OVX1), the basal concentration of LH began to increase significantly 3 months after surgery $(P<0.05)$, in December, remained around $10 \mathrm{ng} / \mathrm{ml}$ during the breeding season, and decreased in September, during the anoestrus 

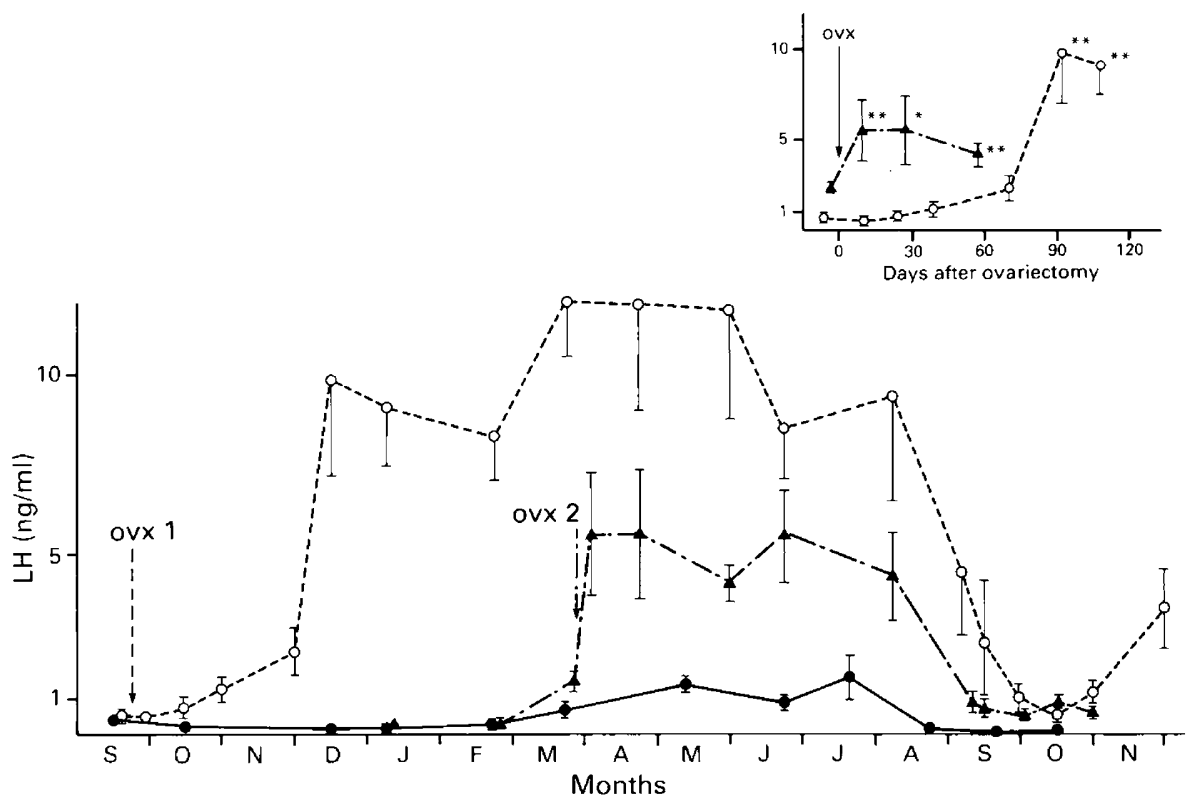

Fig. 2. Seasonal variations in basal concentrations of LH in 6 control ( -5 OVX 1 $(\mathrm{O}-\mathrm{O})$ and 5 OVX $2(\Delta---\Delta)$ females. Values are mean \pm s.e.m. The arrows indicate the time of ovariectomy. In the insert, mean \pm s.e.m. LH levels in OVX $1(\mathrm{O}---O)$ and OVX $2(\boldsymbol{\Delta}--\mathbf{\Delta})$ females are plotted from the day of ovariectomy $(=$ Day 0$)$.

(Fig. 2). When ovariectomy was performed during the breeding season (OVX2), the concentration of $\mathrm{LH}$ rose significantly as soon as 8 days after ovariectomy $(P<0.05)$, remained around $5 \mathrm{ng} / \mathrm{ml}$ from April to September, and returned to low values during anoestrus $(P<0.05)$. Between April and September, the values of LH were significantly lower in OVX2 than in OVX1 groups $(P<0.05)$.

FSH. In intact females, FSH basal concentrations fluctuated between 20 and $40 \mathrm{ng} / \mathrm{ml}$, without any significant seasonal variation $(P>0.05)$ (Fig. 3).

Ovariectomy performed during the seasonal anoestrus was followed by an immediate rise in FSH concentrations. At 2 weeks after surgery, the mean FSH level was $188 \pm 34 \mathrm{ng} / \mathrm{ml}(P<0 \cdot 01)$. Maximum FSH values were reached 1 month later and remained around $400 \mathrm{ng} / \mathrm{ml}$ until the end of the experiment (Fig. 3). Ovariectomy performed during the breeding season was also followed by a very rapid and transient rise in FSH concentrations, up to $452 \pm 85 \mathrm{ng} / \mathrm{ml} 8$ days after the operation $(P<0.01)$. Thereafter, these levels decreased significantly by $100 \%$, and remained at a plateau significantly lower than in the previous group $(P<0.05)$.

\section{Annual variations of the pituitary response to LHRH injection}

FSH and LH profiles after LHRH injection at different periods of the year. Whatever the period of the year, in intact and ovariectomized females, LHRH injection was followed by a release of LH and FSH (Fig. 4). In intact females, during the seasonal anoestrus, the release of LH reached a maximum 15 min after injection and returned to basal value $2 \mathrm{~h}$ later. During the breeding season, a second peak of $\mathrm{LH}$ occurred $2 \mathrm{~h}$ after the injection. The release of FSH occurred $15 \mathrm{~min}$ after LHRH and lasted about $5 \mathrm{~h}$, without any significant seasonal variation in the pattern of release in the $5 \mathrm{~h}$ following LHRH. Nevertheless, during the breeding season, FSH concentrations were significantly enhanced $24 \mathrm{~h}$ after LHRH injection, when compared to the values observed during 


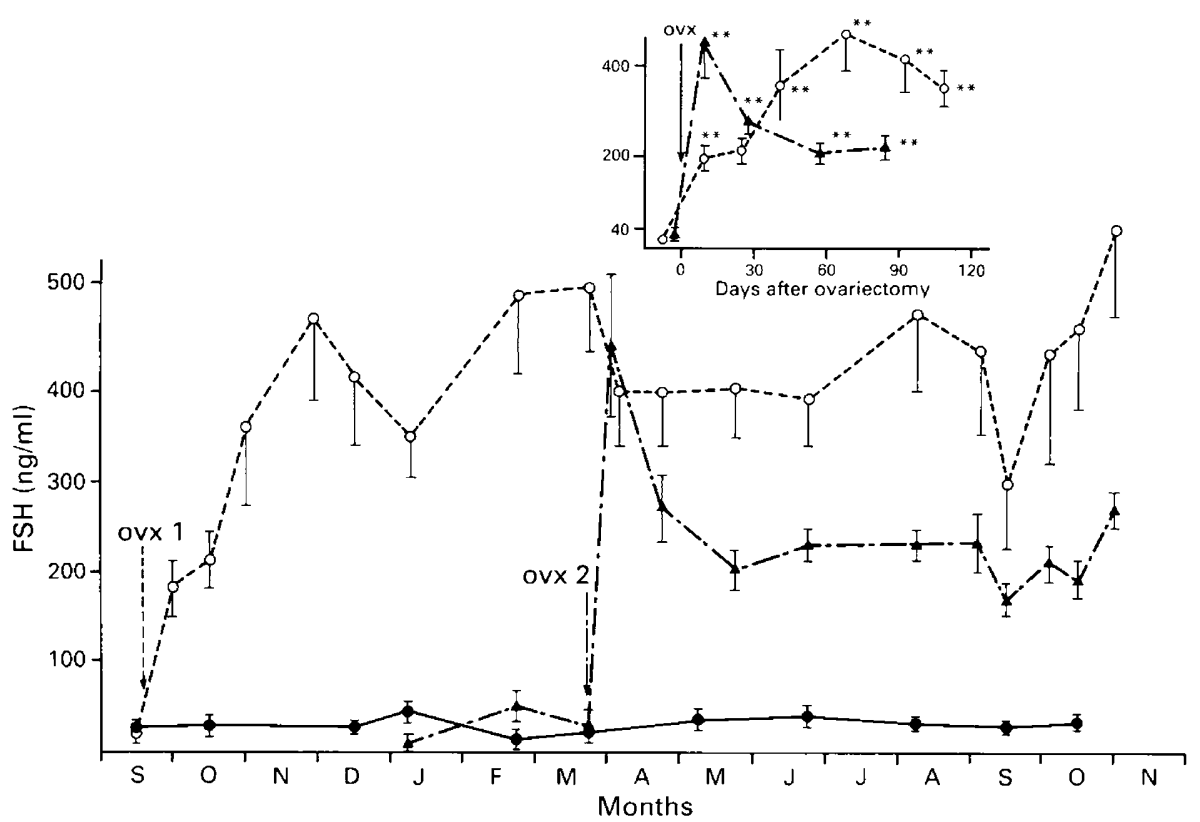

Fig. 3. Seasonal variations in basal concentrations of FSH in 6 control ( -0$), 5$ OVX 1 $(\mathrm{O}-\infty-\mathrm{O})$ and 5 OVX $2(\boldsymbol{\Delta}---\boldsymbol{\Delta})$ females. Values are mean \pm s.e.m. The arrows indicate the time of ovariectomy. In the insert, mean \pm s.e.m. FSH levels in OVX $1\left(\mathrm{O}_{--} \mathrm{O}\right)$ and OVX $2(\boldsymbol{\Delta}---\Delta)$ females are plotted from the day of ovariectomy (=Day 0$) .{ }^{* *} P<0 \cdot 01$.

the seasonal anoestrus (February to July: $103 \pm 18 \mathrm{ng} / \mathrm{ml}, n=23$, vs September to December: $25 \pm 4 \mathrm{ng} / \mathrm{ml}, n=18, P<0.05)$.

In females ovariectomized during the seasonal anoestrus (OVX1), the peak level of LH occurred $15 \mathrm{~min}$ after $\mathrm{LHRH}$, and the basal value was reached $2 \mathrm{~h}$ later. After ovariectomy during the breeding season (OVX2), the same profile was found: the 2 nd LH peak found during the breeding season in intact hares never appeared in ovariectomized females.

In the two groups of experimental animals, the amount of FSH released during $5 \mathrm{~h}$ after LHRH was significantly higher following ovariectomy $(P<0.01)$. There was no significant seasonal variation in the FSH profile after LHRH, and, in contrast to the control group during the breeding season, there was no increase in FSH concentrations $24 \mathrm{~h}$ after LHRH. Furthermore, the pituitary response remained lower in OVX2 than in OVX1 females (Fig. 4).

Seasonal changes in $L H$ released 15 min after $L H R H$. In intact females, the peak level of $L H$ reached $15 \mathrm{~min}$ after LHRH was minimum from September to December, increased between January and August, and returned to low values in September (Fig. 5a). In the OVX1 group, the peak level increased significantly as early as October $(P<0.05)$, was maximum from December to April, and then decreased progressively until October. In the OVX2 group, the peak values fluctuated between 30 and $50 \mathrm{ng} / \mathrm{ml}$, without any significant seasonal variation (Fig. 5a). When compared to the control animals, the values in OVX1 females were significantly higher from October to December, and significantly lower from June to August. The values in the OVX2 group decreased slightly after the operation, and became lower than those of the control group until September and lower than in the OVX1 group until May $(P<0.05)$.

Seasonal changes in LH released 120 min after $L H R H$. In intact females, the concentration of $\mathrm{LH}$ reached $2 \mathrm{~h}$ after LHRH was minimum until December, began to rise in January to a maximum between March and July, and returned to low values in September. When experimental females were compared to the control, the LH values were significantly lower from March to July (OVX1), or immediately after ovariectomy, from April to July (OVX2) (Fig. 5b). 
(Iس/6u) HSł
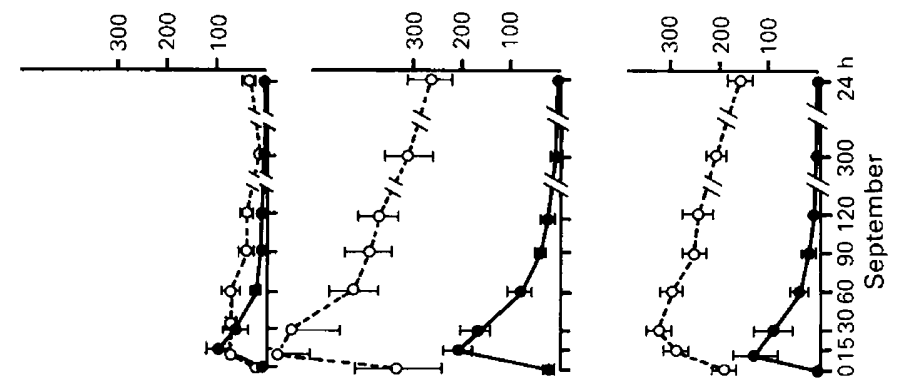

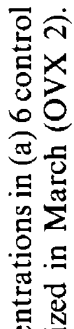
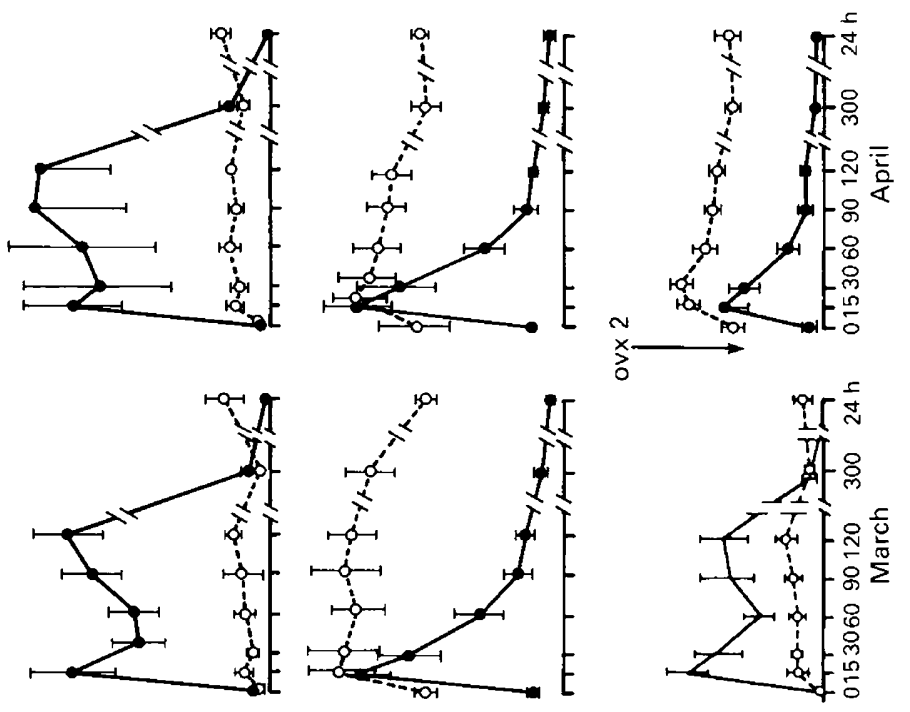

定

要

这

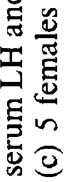

동

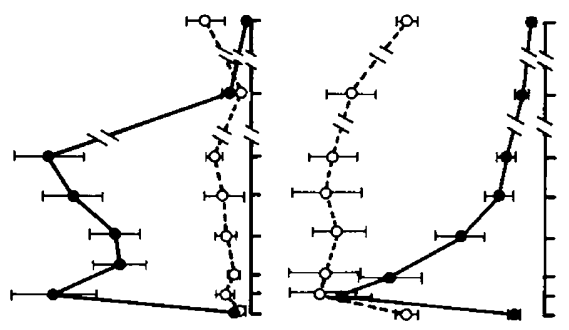

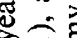

原

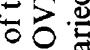

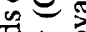

닝

要

跣.

这

胥.

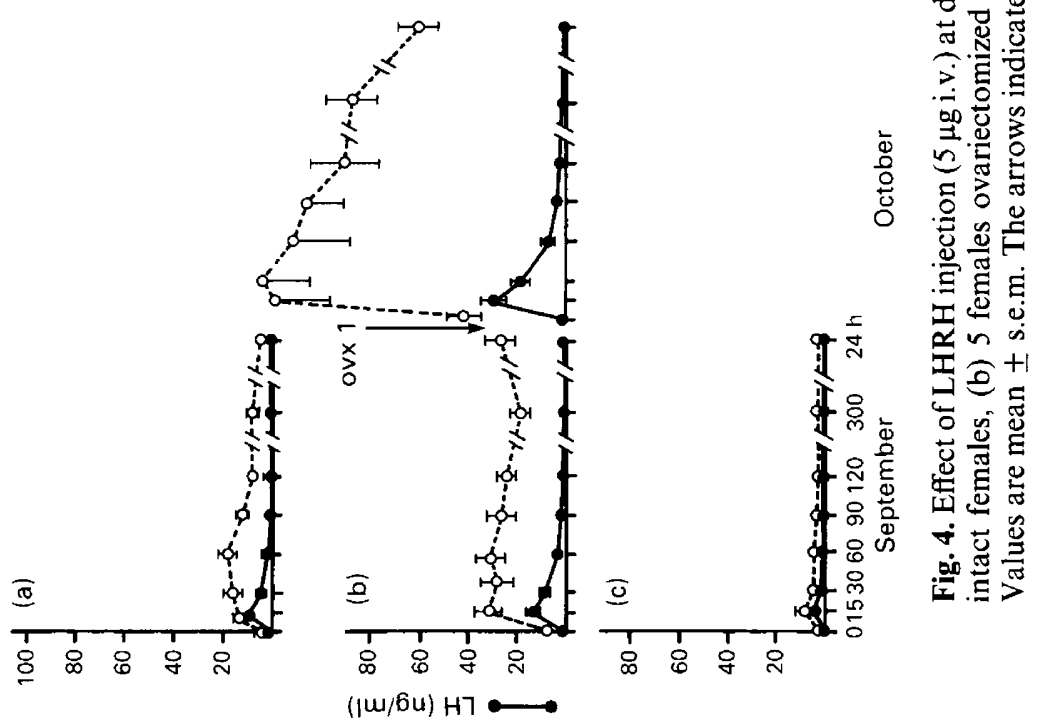




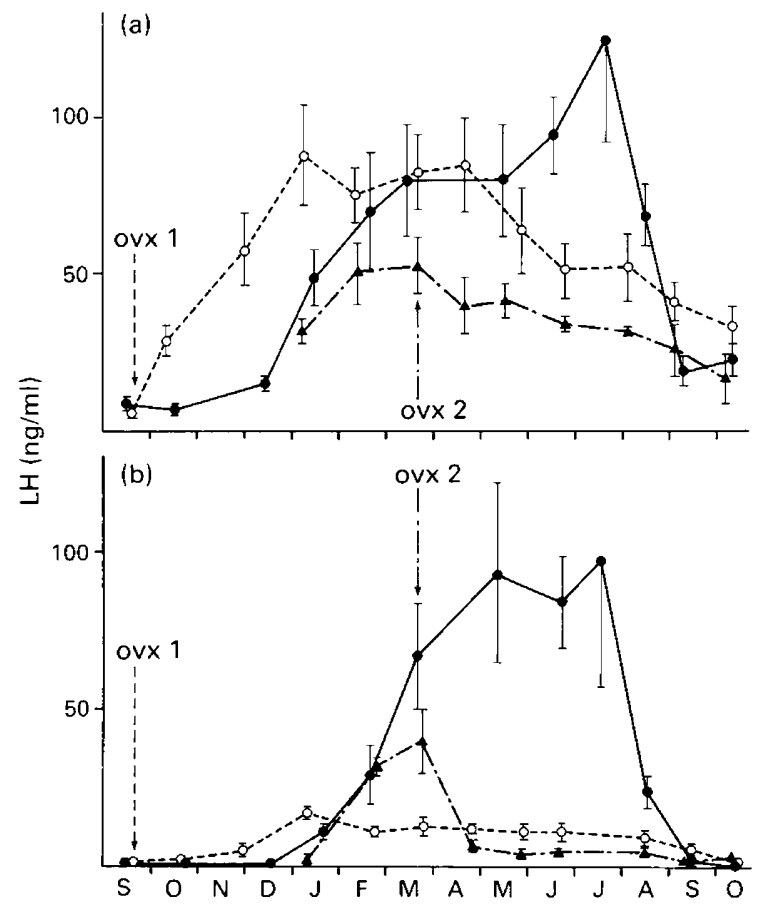

Fig. 5. Seasonal variations in peak concentrations of $\mathrm{LH}$ at (a) $15 \mathrm{~min}$ and (b) $2 \mathrm{~h}$ after LHRH. Values are mean \pm s.e.m. for 6 control $\left(O_{-}\right), 5$ OVX $1\left(O_{--\infty}\right)$ and 5 OVX 2 $(\Delta---\Delta)$ females. The arrows indicate the time of ovariectomy.

\section{Discussion}

The radioimmunoassay system developed for sheep and fox FSH can also be used to measure hare FSH, in contrast to a rabbit-antirabbit FSH system previously tested, which produced non-parallel inhibition curves (M. Blanc, M. Meunier \& J. C. Poirier, unpublished). As shown in a previous paper, in intact doe hares, there is a clear seasonal variation in LH basal concentrations, which remain undetectable during the anoestrus (September to January) and are maximum from March to July (Caillol et al., 1986). The pituitary LH response to LHRH is also maximum from March to July, and, from January to August, a 2nd peak of LH appears $2 \mathrm{~h}$ after injection, in ovulating as well as in non-ovulating females. In contrast, FSH concentrations remain around basal values and the profile of FSH release during the $5 \mathrm{~h}$ following LHRH injection is not modified throughout the year; during the breeding season, a 2nd rise in FSH concentrations occurs $24 \mathrm{~h}$ after LHRH injection, in relation to the occurrence of ovulation (ovulating $v s$ non-ovulating hares: $107 \pm 18 \mathrm{ng} / \mathrm{ml}$, $n=22$, and $32 \pm 10 \mathrm{ng} / \mathrm{ml}, n=10$ ) (Caillol et al., 1986). A similar profile of FSH has been described in the rabbit after mating (Osteen \& Mills, 1979; Meunier et al., 1983).

To our knowledge, few data are available concerning seasonal variations of LH and FSH in induced ovulators. In another hare species, Lepus americanus, Davis \& Meyer (1972) have shown an increase in pituitary content of both gonadotrophins and in serum LH concentrations during the breeding season. In the ferret, Donovan \& ter Haar (1977) described higher plasma concentrations of FSH in anoestrous than in oestrous females, while LH values did not differ significantly, and a greater gonadotrophin response to LHRH in anoestrous than in oestrous females. In seasonal breeders with spontaneous ovulation, there is a discrepancy in the results concerning seasonal 
variation of FSH. In the mare, there was no seasonal variation in FSH pituitary content or plasma levels (Turner et al., 1979; Hart et al., 1984; Silvia et al., 1986). However, LHRH-induced release of FSH decreased as the breeding season approached (Silvia et al., 1987). In the ewe, the results are conflicting: according to Walton et al. (1977) there was no seasonal variation in plasma FSH concentrations, although Findlay \& Cumming (1976) and McNatty et al. (1984) reported a seasonal variation of plasma FSH which could be related to the seasonal variation in the pituitary content of FSH described by Thimonier \& Mauléon (1970).

After ovariectomy in the hare, short-term changes in LH basal concentrations are quite different for the two seasons of ovariectomy: the LH rise, which is immediate when ovariectomy is performed during the breeding season (OVX2), is delayed when ovariectomy is performed during the seasonal anoestrus (OVX1). This suggests a negative feed-back effect of ovarian secretions on LH basal concentrations only during the breeding season. In long-term ovariectomized females, the evolution of $\mathrm{LH}$ is similar to that in intact females, with significantly increased values during the breeding season, and low levels during the next anoestrus, suggesting a direct central effect of season, and probably of photoperiod on the regulation of LH secretion, as already described in the snow-shoe hare (Davis \& Meyer, 1973), in the mare (Garcia \& Ginther, 1976), and in the ewe (Karsch et al., 1984). The increased sensitivity to oestradiol negative feed-back during seasonal anoestrus is well documented in the ewe (Karsch et al., 1984) and in the goat (Mori et al., 1987). In the brown hare, a differential role of oestradiol control upon LH secretion remains to be demonstrated.

In ovariectomized brown hares, the seasonal changes in $\mathrm{LH}$ release after LHRH are less important than those of the basal concentrations. In females ovariectomized during the seasonal anoestrus, the rise in the pituitary LH response to LHRH, which begins as early as October, suggests a negative feed-back effect of ovarian secretions during the anoestrus. From April to September, in both groups of ovariectomized females, the lower peak level of LH 15 min after LHRH and the absence of the 2 nd LH peak $2 \mathrm{~h}$ after LHRH suggest a positive feed-back effect of ovarian secretions during the breeding season, allowing an enhanced duration of $\mathrm{LH}$ secretion after LHRH in intact females. A possible role of periovulatory progesterone and/or oestrogens (released after the first LH rise) in the induction of this 2nd LH peak can be suspected (Caillol et al., 1986).

Whatever the season, ovariectomy is followed by an immediate rise in FSH basal concentrations; in the long term, there are no more changes in FSH concentrations. Similar results are obtained concerning the evolution of the pituitary FSH response to LHRH after ovariectomy. This suggests a negative control of the ovary throughout the year. During the seasonal anoestrus, the quiescent ovary could be responsible for the synthesis of oestradiol and inhibin, accounting for the immediate FSH rise after ovariectomy performed in September. The 2nd rise in FSH concentrations observed during the breeding season in intact females $24 \mathrm{~h}$ after LHRH never appears in ovariectomized females, and could be related to the completion of ovulation, as already suggested. In the rabbit, the post-ovulatory surge of FSH is not mediated by LHRH, but might be triggered by ovarian factors other than oestradiol (Mills et al., 1983; Mills \& Copland, 1983).

Few data are available concerning the relative roles of season and ovarian secretions on FSH regulation. In the snowshoe hare, a rise in pituitary FSH content occurred only when ovariectomy was performed during the breeding season (Davis \& Meyer, 1973). The secretion of FSH appeared to be seasonal in the ovariectomized mare (Freedman et al., 1979) which exhibited fewer peaks in FSH concentrations in winter than in summer, even though mean FSH values did not differ between seasons (Thompson et al., 1987). As in the brown hare, short-term changes in FSH concentrations in ewes ovariectomized during the anoestrous or breeding season did not differ significantly; however, in the ewe, but not in the hare, season influenced FSH secretion over longer periods, increasing it at the onset of the breeding season (Montgomery et al., 1987).

For both gonadotrophins, basal levels and pituitary response to $\mathrm{LHRH}$ remain higher for females ovariectomized during the seasonal anoestrus (OVX1) than for females ovariectomized during the breeding season (OVX2). This could be due to a long-term modulating effect of 
increased ovarian secretions before the ovariectomy performed during the breeding season; this effect would not appear in 6-months-old females ovariectomized during anoestrus.

Our results support the hypothesis that, in the hare, the regulation of LH secretion involves a direct photoperiodic drive responsible for a seasonal rhythm of basal LH release, independent of ovarian influences, and a negative ovarian feed-back which modifies LH concentrations during the breeding season. In intact hares, the enhanced $\mathrm{LH}$ response after LHRH during the breeding season is related to an acute positive effect of ovarian secretions. The regulation of FSH is less dependent on seasonal influences and remains under negative ovarian control throughout the year.

We thank Miss Aline Solari and Mr Daniel Allain for help with statistics; Mrs Bernadette Rossano for skilful technical assistance; Dr G. D. Niswender for the LH GDN-15 antiserum; Dr L. E. Reichert for the ovine LH and FSH, and canine pituitary standards; and Dr R. Scholler for facilities to perform hormone assays in the laboratories of the Fondation de Recherche en Hormonologie.

\section{References}

Caillol, M., Meunier, M., Mondain-Monval, M. \& Simon, P. (1986) Seasonal variations in the pituitary response to LHRH in the brown hare (Lepus europaeus). $J$. Reprod. Fert. 78, 479-486.

Davis, G.J. \& Meyer, R.K. (1972) The effect of daylength on pituitary FSH and LH and gonadal development of snowshoe hares. Biol. Reprod. 6, 264 269.

Davis, G.J. \& Meyer, R.K. (1973) Seasonal variation in LH and FSH of bilaterally castrated snowshoe hares. Gen. comp. Endocr. 20, 61-68.

Donovan, B.T. \& ter Haar, M.B. (1977) Effects of luteinizing hormone releasing hormone on plasma folliclestimulating hormone and luteinizing hormone levels in the ferret. $J$. Endocr. 73, 37-52.

Findlay, J.K. \& Cumming, I.A. (1976) FSH in the ewe: effects of season, live weight and plane of nutrition on plasma FSH and ovulation rate. Biol. Reprod. 15, 335-342.

Freedman, L.J., Garcia, M.C. \& Ginther, O.J. (1979) Influence of photoperiod and ovaries on seasonal reproductive activity in mares. Biol. Reprod. 20, $567-574$.

Garcia, M.C. \& Ginther, O.J. (1976) Effects of ovariectomy and season on plasma luteinizing hormone in mares. J. Endocr. 98, 958-962.

Hart, P.J., Squires, R.L., Imel K.J. \& Nett, T.M. (1984) Seasonal variation in hypothalamic content of gonadotropin-releasing hormone ( $\mathrm{GnRH})$, pituitary receptors for GnRH and pituitary content of luteinizing hormone and follicle-stimulating hormone in the mare. Biol. Reprod. 30, 1055-1062.

Karsch, F.J., Bittman, E.L., Foster, D.L., Goodman, R.L., Legan, S.J. \& Robinson, J.E. (1984) Neuroendocrine basis of seasonal reproduction. Recent Prog. Horm. Res. 40, 185-232.

Martinet, L. \& Moret, B. (1971) Observations préliminaires sur la reproduction du lièvre européen (Lepus europaeus Pallas) en captivité; influence du photopériodisme. In Actes du Xème congrès de l'Union Internationale des Biologistes du gibier, Paris, pp. 553-561. Office national de la Chasse.

McNatty, K.P., Hudson, N.L., Henderson, K.M., Lun, S., Heath, D.A., Gibb, M., Ball, K., McDiarmid, J.M. \&
Thurley, D.C. (1984) Changes in gonadotrophin secretion and ovarian antral follicular activity in seasonally breeding sheep throughout the year. $J$. Reprod. Fert. 70, 309-321.

McNeilly, J.R., McNeilly, A.S., Walton, J.S. \& Cunningham, F.J. (1976) Development and application of a heterologous radioimmunoassay for ovine follicle-stimulating hormone. J. Endocr. 70, 69-79.

Meunier, M. \& Martinet, L. (1986) Role of different photoperiodic treatments on the growth of the testis in juvenile and adult brown hares (Lepus europaeus Pallas). In Endocrine Regulations as Adaptive Mechanisms to the Environment, pp. 155-159. Eds I. Assenmacher \& J. Boissin. CNRS, Paris.

Meunier, M., Hulot, F., Poirier, J.C. \& Torres, S. (1983) A comparison of ovulatory gonadotropic surge in two rabbit strains: no evidence for a relationship between LH or FSH surge and factors of prolificacy. Reprod. Nutr. Develop. 23, 709-715.

Mills, T.M. \& Copland, J.A. (1983) Effects of castration and estradiol treatment on the postovulatory secretion of follicle-stimulating hormone in the mated rabbit. Biol. Reprod. 28, 306-311.

Mills, T.M., Copland, J.A., Coy, D.H. \& Schally, A.V. (1983) Is the postovulatory release of folliclestimulating hormone in the rabbit mediated by luteinizing hormone releasing hormone? Endocrinology 113, 1020-1024.

Mondain-Monval, M., Caillol, M. \& Meunier, M. (1985) Heterologous radioimmunoassay of $\mathbf{L H}$ in two seasonally breeding animals: hare (Lepus europaeus) and mink (Mustela vison). Can.J. Zool.63, 1339-1344.

Mondain-Monval, M., Smith, A.J., Simon, P., Moller, O.M., Scholler, R. \& McNeilly, A.S. (1988) Effect of melatonin implantation on the seasonal variation of FSH secretion in the male blue fox (Alopex lagopus). J. Reprod. Fert. 83, 345-354.

Montgomery, G.W., Martin, G.B., Blanc, M.R. \& Pelletier, J. (1987) Season influences FSH concentration in ovariectomized Ile de France ewes. $J$. Reprod. Fert. 80, 271-277.

Mori, Y., Tanaka, M., Maeda, K., Hoshino, K. \& Kano, Y. (1987) Photoperiodic modification of negative 
and positive feedback effects of oestradiol on LH secretion in ovariectomized goats. J. Reprod. Fert. 80, 523-529.

Osteen, K.G. \& Mills, T.M. (1979) Serum LH and FSH levels in the pregnant rabbit. Proc. Soc. exp. Biol. Med. 162, 454457.

Silvia, P.J., Squires, E.L. \& Nett, T.M. (1986) Changes in the hypothalamic-hypophyseal axis of mares associated with seasonal reproductive recrudescence. Biol. Reprod. 35, 897-905.

Silvia, P.J., Squires, E.L. \& Nett, T.M. (1987) Pituitary responsiveness of mares challenged with $\mathrm{GnRH}$ at various stages of the transition into the breeding season. J. Anim. Sci. 64, 790-796.

Thimonier, J. \& Mauléon, P. (1970) Variations saisonnières des activités hypophysaires des brebis de race Ile de France. In La Photorégulation de la Reproduction chez les Oiseaux et les Mammifères, pp. 471-480. Eds J. Benoît \& I. Assenmacher. CNRS, Paris.

Thompson, D.L., McNeill, D.R., Wiest, J.J., St Georges, R.L., Jones, L.S. \& Garza, F. (1987) Secretion of luteinizing hormone and follicle stimulating hormone in intact and ovariectomized mares in summer and winter. J. Anim. Sci. 64, 247-253.

Turner, D.D., Garcia, M.C. \& Ginther, O.J. (1979) Follicular and gonadotropic changes throughout the year in pony mares. Am. J. vet. Res. 40, 1694-1700.

Walton, J.S., McNeilly, J.R., McNeilly, A.S. \& Cunningham, F.J. (1977) Changes in concentrations of follicle-stimulating hormone, luteinizing hormone, prolactin and progesterone in the plasma of ewes during the transition from anoestrus to breeding activity. J. Endocr. 75, 127-136.

Received 6 June 1989 